\title{
PENGARUH DUKUNGAN SOSIAL TERHADAP HARGA DIRI REMAJA DESA WONOAYU KECAMATAN WAJAK
}

\author{
Achmad Zulkifli Adnan \\ Mauliawati Fatimah \\ Munaela Zulfia \\ Fina Hidayati \\ email: f.guidance@yahoo.com \\ Fakultas Psikologi \\ Universitas Islam Negeri Mulana Malik Ibrahim Malang \\ Jl. Gajayana 50 Malang Jawa Timur
}

\begin{abstract}
Abstrak- Tujuan penelitian ini adalah untuk mengetahui pengaruh dukungan sosial terhadap harga diri pada remaja Desa Wonoayu Kecamatan Wajak. Hipotesis yang diajukan adalah adanya pengaruh dukungan sosial terhadap harga diri remaja Desa Wonoayu Kecamatan Wajak. Adapun responden dalam penelitian ini adalah 103 orang dengan menggunakan instrumen dukungan sosial dan instrumen harga diri. Data yang terkumpul dianalisis menggunakan teknik analisis Regression pada SPSS 16.0 for windows. Hasil dari penelitian ini menunjukkan adanya pengaruh dukungan sosial terhadap harga diri remaja Desa Wonoayu Kecamatan Wajak dengan hasil signifikansi tinggi dengan nilai $p<0,05(p=0,000)$. Pengaruh dukungan sosial menunjukkan nilai 15,5\% terhadap harga diri dan 84,5\% lainnya dipengaruhi oleh faktor - faktor diluar dukungan sosial. Sehingga dapat diindikasikan ada beberapa factor lain yang mempengaruhi remaja desa Wonoayu dalam menghargai dirinya.
\end{abstract}

Keyword: dukungan sosial, harga diri, remaja

PSIKOISLAMIKA. Jurnal Psikologi Islam (JPI) copyright @ 2016 Pusat Penelitan dan Layanan Psikologi. Volume 13 Nomor 2 Tahun 2016

\section{PENDAHULUAN}

Masa remaja adalah masa dimana remaja dituntut untuk bersosialisasi dan beradaptasi dengan lingkungannya. Remaja selain sebagai makhluk individu, juga sebagai makhluk sosial. Sebagai makhluk individu, remaja harus bertanggungjawab terhadap dirinya sendiri baik dalam memenuhi kebutuhan maupun menjaga dirinya dari hal-hal yang dapat merusak. Sebagai makhluk sosial, remaja harus mampu berhubungan dengan remaja lain (Faizatul Amilin dan Retno Lukitaningsih, 2014).

Masa adolescence, menurut Hurlock (1980:206), mencakup kematangan mental, emosional, sosial, dan fisik. Masa remaja ditandai oleh perubahanperubahan fisik dan psikologis yang pesat. Remaja berada pada masa transisi dari kanak-kanak menuju ke dewasa. Pada masa ini individu akan mengenali tugas perkembangan dalam dirinya, salah satunya adalah perkembangan sosial. Salah satu bentuk perkembangan sosial adalah interaksi sosial dengan teman. Interaksi sosial dengan teman merupakan wujud aktualisasi diri individu di lingkungan sekolah. Hal ini merupakan unsur penting untuk memenuhi kebutuhan harga diri. Adanya interaksi sosial, maka individu dapat menemukan jati dirinya. Apabila interaksi sosial tersebut tidak berjalan dengan baik, maka individu tersebut terindikasi mempunyai masalah dalam dirinya. Dalam hal ini, dibutuhkan kemampuan individu untuk memahami dirinya agar mendapatkan harga diri di lingkungannya. 
Farzaee (2012) menemukan adanya hubungan yang positif antara dukungan sosial dan harga diri. Selain itu dalam penelitian ini ditemukan bahwa dukungan sosial keluarga mampu memprediksi kebahagiaan $(r 0,08)$. Hubungan erat antara harga diri dan dukungan sosial oleh keluarga bisa berasal dari pemenuhan kebutuhan tentang harga diri dan kebutuhan sosial. Hubungan positif antara dukungan sosial dengan harga diri juga ditunjukkan hasil oleh penelitian Kumar dkk (2014). Hal lain yang menarik adalah dukungan sosial memiliki hubungan negatif dengan agresi.

\section{Dukungan Sosial}

Menurut Cohen \& Hoberman (dalam Isnawati \& Suhariadi, 2013) dukungan sosial mengacu pada berbagai sumber daya yang disediakan oleh hubungan antar pribadi seseorang. Dukungan sosial memiliki efek yang positif pada kesehatan, yang mungkin terlihat bahkan ketika tidak berada dibawah tekanan yang besar.

Rook (dalam Andarini \& Fatma, 2013) mengatakan bahwa dukungan sosial merupakan salah satu fungsi dari ikatan sosial, dan ikatanikatan sosial tersebut menggambarkan tingkat kualitas umum dari hubungan interpersonal. Ikatan dan persahabatan dengan orang lain dianggap sebagai aspek yang memberikan kepuasan secara emosional dalam kehidupan individu. Menurut Sarafino (1994), dukungan sosial adalah pemberian kenyamanan, kepedulian, penghargaan, atau bantuan yang dirasakan individu yang diterima dari orang lain atau kelompoknya. Dukungan sosial membuat individu merasa nyaman, dicintai, dihargai, dan dibantu oleh orang lain maupun suatu kelompok.

Dukungan sosial yang diterima dapat membuat individu merasa tenang, diperhatikan, dicintai, timbul rasa percaya diri dan kompeten. Dukungan sosial adalah pemberian informasi baik secara verbal maupun non verbal, pemberian bantuan tingkah laku atau materi yang didapat dari hubungan sosial yang akrab, yang membuat individu merasa diperhatikan, bernilai dan dicintai.

Faktor-faktor yang mempengaruhi dukungan sosial menurut Stanley (2007), adalah kebutuhan fisik, meliputi sandang, pangan dan papan. Kebutuhan sosial, Kebutuhan psikis Jika seseorang sedang menghadapi masalah baik ringan maupun berat, maka orang tersebut akan cenderung mencari dukungan sosial dari orang-orang sekitar sehingga dirinya merasa dihargai, diperhatikan dan dicintai (Aziz dan Fatma, 2013).

\section{Harga Diri}

Baron \& Byrne berpendapat bahwa harga diri merupakan evaluasi diri yang dibuat oleh setiap individu, sikap seseorang terhadap dirinya sendiri dalam rentang dimensi positif - negatif. Hal ini sebagian didasarkan pada proses perbandingan sosial.

Coopersmith (Pratiwi, 2011) menyebutkan terdapat empat aspek dalam Self-esteem yaitu power, significance, virtue, dan competence. Kekuatan atau power menunjukan adanya kemampuan seseorang untuk dapat mengatur dan mengontrol tingkah laku serta mendapat pengakuan atas tingkah laku tersebut dari orang lain. Keberartian atau significance menunjukan pada kepedulian, perhatian, afeksi dan ekspresi cinta yang di terima oleh seseorang dari orang lain yang menunjukkan adanya penerimaan dan popularitas individu dari lingkungan sosial. Kebajikan atau virtue menunjukan suatu ketaatan untuk mengikuti standar moral dan etika serta agama dimana individu akan menjauhi tingkah laku yang harus di hindari dan melakukan tingkah laku yang di izinkan oleh moral, etika dan agama. Kemampuan atau competence menunjukan suatu performasi yang tinggi untuk memenuhi kebutuhan dan mencapai prestasi (need of achievement) dimana level dan tugas-tugas tersebut tergantung pada variasi usia seseorang.

Menurut Coopersmith, (1967) ada beberapa faktor yang dapat meningkatkan dan menurunkan penghargaan seseorang terhadap dirinya sendiri. Pertama, penerimaan atau penghargaan terhadap diri (self derogtrion). Indvidu yang berharga akan memiliki penilaian yang lebih baik atau positif terhadap dirinya, sebaliknya individu yang merasa dirinya tidak berharga akan memiliki penilaian atau harga diri yang negatif. Kedua, kepemimpinan atau popularitas (Leadership/Popularity). Penilaian atau keberatian diri diperoleh seseorang pada saat seseorang harus berperilaku sesuai dengan tuntutan sosialnya menandakan kemampuan untuk membedakan dirinya dengan orang lain atau lingkungan tersebut. Dalam situasi ini seseorang akan menerima dirinya serta membuktikan seberapa besar pengaruh dirinya atau popularitas diantara teman-teman sebayanya. Ketiga, keluarga - orang tua (Family-Parents) merupakan proporsi terbesar yang mempengaruhi pembentukkan harga diri. Hal ini disebabkan orang tua dan keluarga merupakan model pertama dalam proses imitasi, dimana anak akan memberikan penilaian terhadap dirinya sebagaimana orang tua menilai dirinya yang berlangsung dalam jangka 
waktu yang relatif cukup lama. Keempat, asertivitas - kecemasan. Seseorang cenderung terbuka dalam menerima keyakinan (belief), nilai-nilai (Values), sikap (attitude), dan aspek moral dari seseorang maupun lingkungan tempat dimana seseorang berada jika dirinya diterima dan dihargai. Sebaliknya seseorang cenderung mengalami kecemasan bila dirinya ditolak (rejection) oleh lingkungannya.

\section{METODE}

Penelitian ini menggunakan dua variabel penelitian, yaitu variabel bebas atau variabel $X$ dan variabel terikat atau variabel $Y$. Adapun veriabel bebas dalam penelitian ini adalah dukungan sosial dan variable terikat dalam penelitian ini adalah harga diri.

Metode pengumpulan data yang digunakan dalam penelitian ini menggunakan skala dengan model Likert. Instrument penelitian ini terdiri dari dua instrumen penelitian, yaitu skala dukungan sosial dan harga diri. Populasi yang diambil pada penelitian ini adalah remaja yang berada di Desa Wonoayu Kecamatan Wajak Kabupaten Malang. Subjek yang digunakan sebanyak 103 orang.

Alat ukur yang digunakan adalah skala dukungan sosial yang dan skala harga diri yang telah diadaptasi oleh peneliti. Pada skala dukungan sosial dengan jumlah 23 aitem diperoleh kefisien reliabilitas sebesar 0,825 dengan jumlah 17 aitem yang sahih.

Sedangkan pada skala harga diri dengan jumlah 29 aitem diperoleh kefisien reliabilitas sebesar 0,793 dengan jumlah 15 aitem.

Data yang terkumpul dianalisis dengan menggunakan teknik regresi sederhana, untuk mengetahui pengaruh antara kedua variabel yakni dukungan sosial (variabel bebas) dan harga diri (variabel tergantung). Untuk pengolahan data, perhitungan ini dilakukan dengan menggunakan program SPSS-16 for windows.

\section{HASIL}

Berdasarkan hasil data deskripsi variabel dukungan sosial memiliki nilai rata-rata sebesar 59,97 , nilai terkecil (minimum) yaitu 41 , nilai tertinggi (maksimum) yaitu 70 dan nilai standar deviasi sebesar 5,971 . Sedangkan variabel harga diri memiliki nilai rata-rata sebesar 52,5, nilai terkecil (minimum) yaitu 28 , nilai terbesar (maksimum) yaitu 63 dan nilai standar deviasi sebesar 5,553.

Data rata-rata tingkat dukungan sosial, diketahui bahwa mayoritas remaja sebanyak 70 orang $(68 \%)$ termasuk dalam kategori dukungan sosial sedang. Sementara yang memiliki dukungan sosial tinggi sebanyak 26 orang $(25,2 \%)$ dan hanya 7 orang $(6,8 \%)$ yang memiliki kategori dukungan sosial rendah.

Untuk harga diri diketahui bahwa mayoritas subjek penelitian sebanyak 80 orang $(77,7 \%)$ termasuk dalam kategori harga diri sedang. Sementara yang memiliki harga diri tinggi sebanyak 15 orang $(14,6$ $\%)$ dan hanya 8 orang $(7,8 \%)$ yang memiliki kategori dukungan sosial rendah.

Hasil menunjukkan nilai $R=0,394$ dan $R$ Square $=0,155$ yang memiliki arti bahwa $15,5 \%$ variabel dukungan sosial memiliki pengaruh terhadap variabel harga diri dan $84,5 \%$ lainnya dipengaruhi oleh faktor-faktor lain. Hasil anova diperoleh nilai $F$ hitung sebesar 18.588 dengan taraf signifikansi $p$ sebesar $0,000 \quad(p<0,05)$. Hal ini menunjukkan hasil yang signifikan dan mengindikasikan adanya pengaruh dukungan sosial terhadap harga diri remaja Desa Wonoayu, Kecamatan Wajak,. Coefficiences menunjukkan bahwa nilai dari konstanta regresi dukungan sosial adalah 30.516 dan nilai konstanta regresi harga diri adalah 0,367 . Dengan demikian dapat dibentuk persamaan garis regresi linier sederhana sebagai berikut:

$$
\begin{aligned}
& Y=a+b X \\
& Y=30,516+0,367 X .
\end{aligned}
$$

Hasil analisis regresi pada remaja putri menunjukkan $R$ square sebesar $25,6 \%$ yang mengindikasikan dukungan sosial memiliki kontribusi sebesar $25,6 \%$ terhadap variabel harga diri mereka dan $74,4 \%$ lainnya dipengaruhi oleh factor-faktor lain diluar variabel dukungan sosial.

\section{DISKUSI}

Berdasarkan hasil penelitian, mayoritas remaja yang berada di Desa Wonoayu memiliki tingkat dukungan sosial yang cukup baik dan hanya sedikit remaja yang memiliki tingkat dukungan sosial rendah. Dalam hal ini, tidak semua orang mendapatkan dukungan sosial seperti yang diharapkannya. Setidaknya ada 3 faktor yang menyebabkan seseorang menerima dukungan (Sarafino, 1994).

\section{Potensi Penerima Dukungan}

Seseorang dapat memperoleh dukungan yang diharapkannya maka dia harus bersikap sosial, mempunyai sifat menolong, dan hal baik lainnya. 


\section{Komposisi dan Struktur Jaringan Sosial}

Hubungan yang dimiliki individu dengan orang-orang dalam keluarga dan lingkungannya dapat bervariasi dalam ukuran (jumlah orang yang sering berhubungan dengan individu), frekuensi hubungan (seberapa sering individu bertemu dengan orang-orang tersebut), komposisi (apakah orangorang tersebut keluarga, teman, rekan kerja, dan sebagainya), dan kedekatan hubungan

Hal ini berarti subjek memperoleh dukungan sosial seperti yang diharapkannya, memperoleh kesediaan dari seseorang yang diharapkan dapat menjadi penyedia dukungan yang subjek butuhkan, dan memperoleh kedekatan hubungan yang dimiliki subjek dengan orang-orang dalam keluarga maupun lingkungannya.

Dilihat dari tingkat harga diri remaja di Desa Wonoayu Kecamatan Wajak, mayoritas berada pada tingkat kategori sedang, disusul oleh beberapa yang berada dalam kategori tinggi dan hanya sedikit remaja yang memiliki tingkat harga diri rendah. Myers (1992), membagi dua kelompok harga diri berdasarkan tinggi rendahnya. Adapun karakteristik dua kelompok tersebut adalah :

Harga diri tinggi memiliki kecenderungan karakteristik antara lain :Menghormati diri sendiri, Menganggap diri berharga, Tidak menganggap dirinya sempurna atau lebih baik dari orang lain tetapi juga tidak lebih buruk.

Harga diri rendah memiliki kecenderungan karakteristik: Menolak dirinya secara verbal dan aktif, Tidak puas dengan dirinya, Tidak menyukai gambaran dirinya dalam bentuk hubungan dengan orang lain, Tidak menyukai gambaran dirinya dan menginginkan yang berbeda namun tidak yakin akan mampu mengubahnya.

Dapat disimpulkan bahwa remaja yang memiliki harga diri tinggi akan merasa dirinya adalah orang yang berharga, puas akan dirinya sendiri, dapat menerima kritik, tahu akan keterbatasan dirinya, rendah hati, aktif, mandiri, dan berani mengambil resiko. Sedangkan remaja yang memiliki harga diri rendah akan menganggap dirinya tidak berharga, mudah tersinggung, tidak yakin akan kemampuan dirinya sendiri, tidak bersemangat, merasa diasingkan dan mudah menyerah.

Dukungan sosial merupakan salah satu istilah yang digunakan untuk menerangkan bagaimana hubungan sosial menyumbang manfaat bagi kesehatan mental atau kesehatan fisik individu (Maslihah, S. 2011). House (Smet, 1999) menyatakan adanya beberapa aspek yang terlibat dalam pemberian dukungan sosial yaitu aspek emosional, aspek informatif, aspek instrumental dan aspek penilaian. Menurut Stanley (2007), faktor - faktor yang mempengaruhi dukungan sosial adalah kebutuhan fisik, kebutuhan sosial dan kebutuhan psikis.

Sumbangan efektif (SE) variabel dukungan sosial terhadap harga diri remaja di Desa Wonoayu sebesar 15,5\% ditunjukkan oleh koefisien determinan $\left(r^{2}\right)$ sebesar 0,155 . Hal ini memiliki arti bahwa terdapat $84,5 \%$ faktor lain yang mempengaruhi diluar faktor dukungan sosial seperti konsep diri, kemampuan kognitif individu. Hasil penelitian ini menyebutkan bahwa dukungan sosial disertai aspek didalamnya memberikan kontribusi bagi harga diri remaja Desa Wonoayu. Dukungan sosial yang merupakan pertolongan dan dukungan yang diperoleh seseorang dari interaksinya dengan orang lain. Dukungan sosial timbul oleh adanya persepsi bahwa terdapat orang-orang yang akan membantu apabila terjadi suatu keadaan atau peristiwa yang dipandang akan menimbulkan masalah dan bantuan tersebut dirasakan dapat menaikkan perasaan positif untuk meningkatkan harga diri. Faktor yang mempengaruhinya adalah kemampuan kognitif merupakan salah satu faktor yang berpengaruh penting pada harga diri individu. Inteligensi minimal rata-rata dibutuhkan bagi peningkatan harga diri pada diri individu. Individu yang memiliki harga diri yang tinggi berarti individu tersebut memiliki intelegensi yang baik (Coopersmith, 1967).

Hal ini sesuai dengan Weiss (dalam Khera, 2002), yang mengatakan bahwa fungsi dari dukungan sosial juga sangat berpengaruh untuk meningkatkan harga diri individu. Selain itu dengan adanya dukungan yang didapatkan oleh individu, maka individu akan dapat meningkatkan rasa percaya dirinya dan memotivasi penderita menjadi lebih baik, karena individu yang memiliki dukungan sosial yang tinggi cenderung lebih menghayati pengalaman hidupnya sebagai sesuatu yang positif, memiliki rasa percaya diri yang tinggi dan lebih memandang kehidupannya secara optimis dibandingkan dengan individu yang memiliki dukungan sosial yang rendah.

Pengaruh dukungan sosial terhadap harga diri ini lebih didominasi oleh remaja putri yaitu dengan nilai R square sebesar $25,6 \%$. Hal ini menunjukkan $25,6 \%$ dukungan sosial berpengaruh terhadap harga diri remaja putri dan $74,4 \%$ sisanya dipengaruhi oleh faktor lain. Hal ini disebabksn pola pikir mereka yang berbeda dan cara bertindak. remaja putri cenderung lebih memperhatikan perubahan fisiknya dan penerimaan teman sebaya_(Simon dan 
Rosenberg, dalam Stainberg 2002). Meskipun demikian. Ancok (Gufron, 2010) berpendapat bahwa wanita selalu merasa harga dirinya lebih rendah dari pria, seperti perasaan kurang mampu, kepercayaan diri yang kurang atau merasa harus dilindungi. Hal ini karena peran orangtua yang berbeda-beda baik pada pria ataupun wanita. Oleh karena itu peran orang terdekat dalam dukungan sosial sangat dibutuhkan agar terbentuknya harga diri yang positif. Dukungan ini bisa bersumber dari keluarga, teman sebaya ataupun dari masyarakat.

\section{DAFTAR PUSTAKA}

Abdul Aziz \& Anne Fatma. (2013). Hubungan Antara Dukungan Sosial Dengan Penyesuaian Diri Orang Tua Yang Memiliki Anak Autis. Talenta Psikologi 2 (2).

American Psychological Association. (2002). Developing Adolescents A Reference For Professionals. Washington DC.

Amilin, Faizatul dan Retno Lukitaningsih. (2014). Penerapan Konseling Kelompok Kognitif Perilaku Untuk Menurunkan Kecenderungan Menarik Diri Pada Siswa Kelas Xmia 4 Sma Negeri 1 Mantub Lmongan. Jurnal BK UNESA. Vol. 04. No.3. hal 156-165.

Andarini, S.R. Fatma, A. (2013). Hubungan antara Distres dan Dukungan Sosial dengan Prokrastinasi Akademik pada Mahasiswa dalam Menyusun Skripsi. Talenta Psikologi. Vol. II, No, 2, diakses pada tanggal 16 juni 2016/pdf.

Baron, A., Byrne. (2004). Psikologi sosial jilid I. Jakarta: Erlangga

Burnett , Stephanie \&Sarah-Jayne Blakemor. (2009). The Development of Adolescent Social Cognition. Values, Empathy, And Fairness Across Social Barriers: Annals Of The New York Academy Of Sciences. 51-56.

Dispenduk Kabupaten Malang.www. Wajak.go.Id. Diakses Pada 13 Juni 2016.Pukul 22.37.

Hurlock, E.B. (1980). Psikologi Perkembangan. Jakarta: Erlangga.

Kumalasari, Fani \& Nur Ahyani, Latifah. (2012). Psikologi Univers Hubungan Antara Dukungan Sosial Dengan Penyesuaian Diri Remaja Di Panti Asuhan. Jurnal Psikologi Pitutur. Vol. 01. No.01.

Ghufron. (2010). Teori-teori Perkembangan. Bandung: Refika Aditama.Isnawati, Dian, Fendy Suhariadi. 2013. Hubungan antara

\section{KESIMPULAN}

Penelitian ini menunjukkan adanya pengaruh dukungan sosial terhadap harga diri pada remaja desa Wajak. Hal ini menerangkan bahwa individu yang mendapatkan dukungan sosial mempunyai harga diri yang tinggi dalam menjalankan kegiatannya. Mereka akan lebih percaya diri dalam menghadapi hidup.

Dukungan Sosial dengan Penyesuaian Diri Masa Persiapan Pensiun Pada Karyawan PT Pupuk Kaltim. Jurnal Psikologi Industri dan Organisasi.Vol. 02 No.1, hlm 1-6. Diakses pada tanggal 16Juni2016/pdf.

Kasiram, Moh. (2008). Metode Penelitian. Malang: UIN Mapang Press

Khera. (2002). Kiat jitu menjadi pemenang : You Can Win. Alih Bahasa : Tim Penerjemah Mitra Utama. Jakarta PT Prenhallindo \& Pearson Education Asia Pte Ltd.

Maslihah, S. (2011). Studi Tentang Hubungan Dukungan Sosial, Penyesuaian Sosial di Lingkungan Sekolah dan Prestasi Akademik Siswa SMIPIT Assyfa Boarding

Myers, G. E \& Michelle, T.M. (1992). The dynamic of human communication : A Laboratory Approach. New York : Mc. Graw - Hill Inc.

Nurhidayati, Nuni \&Duta Nurdibyanandaru . (2014). Hubungan Antara Dukungan Sosial Keluarga Dengan Self Esteem Pada Penyalahguna Narkoba Yang Direhabilitasi .Jurnal Psikologi Klinis Dan Kesehatan Mental Universitas Airlangga. 03 (03).53-59.

Pratiwi, Lulun Rosana. (2011). Hubungan Kebermaknaan Hidup dengan Self-Esteem pada Penghuni/ Siswa Pusat Rehabilitasi Naarkoba Rumah Damai. Skripsi Sarjana pada FIP

Universitas Negeri Semarang: tidak diterbitkan. School Subang Jawa Barat. Jurnal Psikologi Undip. Vol 10 No. 2, 103-114.

Kumar, Rajesh dkk. (2014). Impact Of Social Support In Relation To Self-Esteem And Aggression Among Adolescents. International Journal Of Scientific And Research Publications, Vol. 4 (12). 
Smet, Bart. (1999). Psikologi Kesehatan. Jakarta : Grasindo

Sarafino, E. P. (1994). Health psychology. New York : John Wiley \& Sons, Inc

Farzaee, Nafiseh. (2012). Self Esteem And Social Support Vs. Student Happiness. International Research Journal Of Applied And Basic Sciences. Vol., 3 (9),
Stang J. (2005). Adolescent Growth And Development. Guidelines For Adolescent Nutrition Services. http://www.Epi.Umn.Edu/Let/Pubs/Adol Book.Shtm

Sugiyono. (2010). Statistika Untuk Penelitian. Bandung: Alfabeta.

Tahir, W.B. Dkk. (2015).Relationship Between Social Support And Self Esteem Of Adolescent Girls. losr Journal Of Humanities And Social Science (losr-Jhss). 20 (1).42-46. 